\title{
Per-Erik Nilsson
}

Uppsala University, Sweden; Sciences-Po Aix, France

\section{Victoria Enkvist}

Uppsala University, Sweden

\begin{abstract}
This article is an analysis of the recognition of the Missionary Church of Kopimism as a faith community by the Swedish state. The analysis draws on post-Foucaultian writings on governmentality and seeks to understand what kind of normative and proscriptive understandings of "religion" guide the process. The authors argue that the recognition reveals fundamental aspects of the Swedish state's performative role in the recognition of faith communities which challenges any unreflective classification of it as "secular."
\end{abstract}

\section{Keywords}

Critical legal theory, critical religion theory, faith communities, governance, governmentality, law, religion, secularism, Sweden

\section{Introduction}

In 2011, Kammarkollegiet, the oldest public authority in Sweden, granted the Missionary Church of Kopimism (MCK) (Det missionerande kopimistsamfundet) official status as a faith community (trossamfund) (Kammarkollegiet, 2011a). The MCK is built on an ethical foundation where all forms of copying, from the biological reproduction of genes to the spreading of digital data, are considered sacred (Gerson, 2013). The recognition refers to the Law of 1998:1593 (Lag om trossamfund), regulating faith communities ratified during the process of separation between the Swedish State and Swedish Church, finalized 1 January 2000. 
As will become clear in this article, recognition of a faith-based community is an implicit recognition of a community as "religious."

In Sweden a recognition of a faith community by the state makes possible certain advantages, such as various types of financial support and legal protection for certain customs. ${ }^{2}$ Recognition by Kammarkollegiet, however, does not in itself grant financial support; it is merely a first step toward it. Obtaining financial support requires that, for example, the community contributes to the reinforcement of the Swedish society's foundational values. It is moreover the government that grants a faith community the eligibility to apply for state funding and it is the Swedish Commission for Government Support to Faith Communities that decides and distributes funding. A case in point is the Jehovah's Witnesses. They are a registered faith community in Sweden but they have been denied financial support by the Swedish government because they encourage their members not to vote, which according to the then government is a negation of the foundational Swedish value of democracy. ${ }^{3}$

As several scholars before us have pointed out, recognizing and managing faith communities in particular and what is being considered as "religion" in general is a curious function of a state that claims to be secular (Beaman, 2012; Sullivan, 2005; Mahmood, 2006). According to the Swedish state (and other secular states) neutrality vis-à-vis "religion" and the separation between state and organized "religion" is regarded as foundational (McGoldrick, 2006; Waller, 1964). Leading scholars of Secularism, like José Casanova (2011) and Charles Taylor (2008), also share this view. However, drawing on critical religion theory, we argue that this attribute of the secular state is not merely a question of designating the boundaries of the "religious" and not "religious" (Cavanaugh, 2009; Fitzgerald, 2007, McCutcheon, 2007; Masuzawa, 2005; Nongbri, 2013). The state's practical need to define these boundaries appears to make the state apparatus a performative arena for what Marcus Dressler and Arvind Mandair call "religion-making" (2011: 19).

Religion-making draws on post-Foucaultian theories of governmentality and is a tool to analyze historical and contemporary conceptualizations and institutionalizations of "religion" and their consequences. In the article, we thus inquire how the Swedish state, through the process of recognition, assumes the role of a sovereign actor by governing the boundaries for what can be legally categorized as "religion" as well as a performative arena for construing "religion." Our aim with the article is to analyze, through the example of the MCK, the Swedish state's recognition of faith-based communities as a technique of "religion"making. We seek to explore whether proscriptive notions of the category "religion," if there are such notions in the first place, have had an impact on the recognizing procedure. Moreover, we seek to reveal whether these notions relate to the foundation of the MCK itself. Finally, we raise a number of questions for future inquiry in relation to the recognition of faith communities, Swedish state neutrality, and secularism and especially the judicial and legislative problems that might emanate from a lack of a coherent definition of what "religion" is.

Our understanding distinguishes itself from analytical approaches that suggest that "religion" and law are separate spheres of human activity that might or might not impact each other (e.g. Edge, 2006; Radan et al., 2005; Turner, 2011). We approach law as a performative technique of modern government that produces and institutionalizes particular power relations, that is certain aspects of human activity as "religious." Our interest in "religion" is thus with the performative intersections of state, law, and "religion." We are thus not conducting legal exegesis to evaluate whether or not the acknowledgment of the MCK was correct, nor are we providing a more appropriate definition of "religion" in law, 
any more than we are providing for an analysis of the MCK as a faith community or if Kopimism, the community's "religion," is real or sincere. ${ }^{4}$

\section{The MCK}

The MCK was founded in the autumn of 2010 in Uppsala by Isak Thomas Gerson and Gustav Nipe. In interviews with us, Gerson describes how he and Nipe wanted to gain recognition for what they saw as "sacred" activities. These activities were the getting together on weekends in chat rooms and through secure connections to share data. The name of their newly found "religion," Kopimism, derives from copy and me and encapsulates the core of the MCK's activities. As Gerson describes it, they saw something "beautiful" and "theological" in this (2014a). Gerson explains how sharing digital data was part of a larger and all-encompassing system of reproduction and copying which is inbuilt into the very foundation of the world - the reproduction and copying of cells, DNA, genes, and so on. The decision to seek recognition was easy. Gerson (2014a) states that "we were sort of already a faith community" and continues "I guess we also wanted to test if we could be recognized. We had nothing to lose except the application fee (500sek).",

Gerson and Nipe have a background in Internet activism and have played significant roles in the Swedish Anti-Piracy Movement (Dahlström, 2011). The Movement has created somewhat of a moral outcry, and prominent figures in it have been sentenced to prison for copyright infringement. ${ }^{6}$ Given these links to the Piracy Movement, when the MCK case became publicly known, it also became a target for journalists and public spokespersons and has contributed to the creation of public skepticism about the real motives of Gerson and Nipe. In the news media in general, and in Christian journals in particular, journalists and public spokespersons denounced the MCK as "a political adventure" (Zetterman, 2012), "a PR-stunt" (Dareberg, 2012), and "a devaluation of religion” (Editorial, 2012).

The MCK submitted their first application to Kammarkollegiet during the spring of 2011. At the time, there were ten to fifteen official members but, when they received recognition in the early winter of the same year, there were according to the founders about four thousand. The MCK does not keep a record of its members; hence further analysis is needed to assess the member base today. Their most active section is located in the city of Umeå in northeastern Sweden. Kopimist churches have also been established in Canada, Japan, and the US.

As we show in our analysis, the MCK came to both challenge and enforce notions of what a legal definition of "religion" entails. As such, the MCK is an interesting case in relation to public conceptions of "religion" and how the boundaries of "religion" and non-"religion" are being negotiated in the modern nation state. Moreover, since the MCK did not exist as an organized faith community in the eyes of the state before its recognition, the case offers an opportunity to analyze the organization of a community in direct relation to Kammarkollegiet's guidelines and thus the opportunity to analyze the impact of these guidelines on the church. The case is also important because it helps us to reveal how an ambiguous understanding of what "religion" entails makes possible for a recognition of virtually any sort of community that simply follows the state guidelines for recognition. This might be problematic from a judicial point of view because, as in the case of the MCK, the core activity of the community is banned by Swedish and international law-that is copying, sharing, and distributing copyrighted material.

The data for our analysis of the recognition of the MCK consist of Kammarkollegiet's guidelines for recognizing faith communities, the Law of 1998, the MCK's applications 
(it took three submissions in 2011 to convince Kammarkollegiet), interviews with Gerson (conducted in 2013-14), and written articles and interventions in the news media by Gerson. We want to emphasize that this is but one case of state recognition in Sweden and that our data are limited. For this reason, the conclusions of this article should be seen as points for further inquiry.

\section{The secular nation state and religion-making}

In many sociological and historical studies of "religion," it is claimed that Sweden in particular and Scandinavia in general are among the most "secular" regions in the world. Ole Riis, for example, states:

The general impression is ... that Scandinavia forms an extreme case of secularization in the sense that religious attitudes are of low intensity, religious beliefs are rather vague, religious behavior is infrequent, and religious authorities have little practical influence on the opinions and ethics of most Scandinavians. (Riis, 1994)

Scholars of this conviction point to the high degree of individualization and liberal values and a decline in church attendance and adherence (e.g. Norris and Inglehart, 2004; Pettersson, 1988; Therborn, 2012). Although there are a number of ways to challenge the thesis (e.g. Thalén, 2006; Willander, 2013), our focus is on state governance of "religion."

Now, the Lutheran Church of Sweden (CS) has been intimately linked to the fashioning of the Swedish nation state. The church has at least up until the 20th century played a fundamental role in terms of education, health, public morality, and citizenship and national identity (see Green, 2011; Lejon, 2013). Regarding the latter, the CS lost its congregational monopoly in 1860, meaning that Swedish citizens could switch congregation away from the CS without being disinherited and expatriated from Swedish territory (see Dahlman, 2009). However, it was first in 1951 with the Freedom of Religion Act that allowed Swedish citizens to leave the CS without joining another congregation. Although a separation between the CS and the state was discussed as early as the 1850 s, it was 150 years later, in 2000 , that a separation took place. But to talk about a strict separation is not accurate as the CS and state are still intimately intertwined on a number of institutional levels, which is regulated by the Law of 1998:1591. The law grants the CS a special status as a faith community whereas other communities are regulated by the Law of 1998:1593 as previously mentioned (Bexell, 2003; Ekstrand, 2002; Pettersson, 2011). The intertwined relation between the CS and the state concerns among other things that the state collects what is commonly referred to as the "Church Tax." The church is an important actor in national rites of passage such as school festivities and the yearly inauguration of the Swedish Parliament, and the church still manages burials in Sweden, regardless of the deceased's "religious" identity (see Bäckström et al., 2004). From an institutional comparative approach, we suggest that the question of separation is misdirected and should instead be posed in relation to how secular states construe and delineate "religion" as governable through the processes of religion-making.

As stated, in order to analyze this process of religion-making, we draw on an analytical framework based largely on post-Foucaultian writings on governmentality and the growing body of literature on religion-making as developed by Dressler and Mandair (2011). With governmentality, we wish to direct attention to how modern government is not reducible to merely state actions, although the state in many cases, as in ours, is an important agent in governing human life, behavior, and interaction (Brown, 2008). We thus see modern 
government as the attempted management of a set of power relations through heterogeneous agents and discourses with, to quote Xavier India (2005: 1), the purpose of regulating "the conduct of conduct, all those more or less calculated and systematic ways of thinking and acting that aim to shape, regulate, or manage the comportment of others." In this regard, law becomes a performative and prescriptive technique or tactic of government to construe "religious" subjects. To quote Foucault (1991: 95), "with government it is a question not of imposing laws on men, but of disposing things... to arrange things in such a way that, through a certain number of means, such and such ends may be achieved."

Regarding the category of "religion" vis-à-vis governmentality, we find Dressler and Mandair's work highly instructive in the sense that we understand contemporary common sense notions of "religion" largely as products of modern government. It has been construed in historical and heterogeneous discursive processes and it has been so in relation to, and in separation from, various and often contradictory understandings of secularism (Dressler and Mandair, 2011: 19). In this regard, "religion" is understood as a modern category, as the result of particular power struggles that took place within European Christendom and its encounters with the New World and that have been conceptualized and institutionalized through colonial enterprises, modern state power, and academia (Nongbri, 2013). Of special importance here is the neutralization of the division between the material or secular world and the spiritual or "religious" world, the former being the object of scientific knowledge and the latter of faith. Timothy Fitzgerald highlights how the idea of "religion" as a superstitious and private sphere of human activity and the "secular" as a rational and public human activity is indebted to the Protestant Reformation and Enlightenment thought. Fitzgerald refers to this as the liberal theology of essentialized "religion" (Fitzgerald, 2007: 26). Moreover, as Tomoko Masuzawa (2005) has forcefully shown, the notion that "religion" is a separate societal sphere has come to be neutralized through the "WorldReligions" discourse and the theory of secularization, suggesting that the secular and the "religious" or secularism and "religion" are two interdependent modern inventions, and not universal entities or processes.

To analyze "religion" as a product of historical and heterogeneous discursive processes and as governmentality, Dressler and Mandair divide the analysis of religion-making into three levels. The first one is religion-making from above (i.e. as a technique of modern governance where particular constellations of power and identities are being construed and made into governable objects). In the case of the MCK, this relates to the Kammarkollegiet's rules and guidelines that demand faith communities take on a particular form of organization to be acknowledged as a faith community. The second one is religionmaking from below (i.e. how particular groups employ particular notions of "religion" to be acknowledged as legitimate "religious" groups, separated from other "social" or "political" groups). This level of analysis relates to how the MCK adapted and adopted the prescriptive rules and guidelines of Kammarkollegiet, both strategically and unconsciously. The third one is religion-making from the outside (i.e. statements from scholars that give legitimacy to the previous two levels through their status as "experts"). This is indeed an important aspect of the analysis of religion-making but beyond the scope of the analysis of this article. However, as our analysis shows, the news media played an important and formative role in the formation of the MCK in a twofold way. The first one correlates to the second level on religion-making, that is how the MCK sought to legitimize their "religion" through interventions in the news media. The second one relates to the third level in Dressler's and Mandair's analysis because public spokespersons via the news media sought to delegitimize 
Kopimism as "religion" thus exercising an outside pressure on the MCK. Thus, although the focus has changed from experts to the news media, the logic of outside essentialization of "religion" remains.

\section{Religion-making from above}

In this section, we analyze the Swedish state's rules and regulations for the recognition of faith communities. The guideline for registration of faith communities is stated in the Law of 1998 and is presented in accessible language on Kammarkollegiet's Web site. The guideline states that a community needs to fulfill four rules to gain recognition: they need (a) some sort of "religious" activity, (b) a charter, (c) a governing board, and (d) a name that sets them apart.

First, for a community to be acknowledged in accordance with the Law of 1998 it needs to conduct some sort of "religious activity" (religiös verksamhet) comprising the central task of arranging "divine service" or "worship" (gudstjänst) or "other gatherings for collective prayer, meditation, or something similar."7 Commenting on the MCK's first application from 2011, Kammarkollegiet pays great attention to the legal definition of a faith community as stated in the Law of 1998, and especially the first aspect of the law, on "religious activity." The law states that worship also includes "other gatherings for the purposes of collective prayer, meditation, or something similar." The emphasis on the word "gathering" demands that the religious activity be institutionalized and collective whilst the phrasing "something similar" leaves it to the whim of the state to decide what activity might actually entail. It is worth pointing out that with the statement "collective prayer, meditation, or something similar," Swedish legislators appear to have sought a more pluralistic definition of "religious activity," which in the preceding Law of 1951 only comprised worship. According to the preparatory work of the Law of 1998, the reason for doing so was to be more inclusive toward communities that do not organize worship in a traditionally Lutheran fashion (see Bill (1997/98: 116)). Here a negotiation of how to deal with the ambiguity of the category of "religion" is taking place. The solution appears simply have been to omit it from the discussion and instead to talk about faith communities.

In Swedish law, what "religion" is meant to signify is unclear and relatively few scholars have worked on this issue (e.g. Enkvist, 2013; Strömberg, 2007). Some legal scholars have however discussed the meaning of "religion" in relation to laws on freedom of "religion." According to Håkan Strömberg, the lack of definition of "religion" causes significant problems for the judiciary (2007: 84). Swedish constitutional law states that "religious" freedom is an absolute freedom, meaning that no infringement can be made in the exercise of "religion." However, without knowing what "religion" signifies, what actually falls under the protection of constitutional law becomes an uncertain matter. Gustaf Petrén and Hans Ragnemalm, for example, argue that "religiosity" needs to be supported by "conviction" and "faith" and striving for something beyond the mundane world (1980: 47). This understanding is a prevailing one in Swedish legal praxis, where "religion" is often reduced to mean faith (Enkvist, 2013: 89). The potential problem that emerges here, as we see it, is that what is to be considered as faith is being judged through a process of exegesis governed by normalized and neutralized notions of "religion" based on a liberal theology of essentialized "religion." Lori Beaman has put it this way:

there is an assumption that we all know what 'religious' freedom is. But Jehovah's Witnesses, aboriginals, Wiccans, Muslims, Sikhs, Buddhists and Jews, to name but a few, would point out 
that we know what 'religious' freedom is as long as it is within the parameters of mainstream Christianity. (2005: 21)

Similarly, in trying to widen the meaning of worship, it imposes and puts emphasis on a certain way of organizing "religious" activity. In the attempt to widen the meaning of worship, the notion of what "religion" entails thus, on the one hand, stands unchallenged as normatively Christian and, on the other hand, makes possible for a wide variety of communities to be recognized as "religious" as long as they are construed according to Kammarkollegiet's guidelines.

The second demand stated by Kammarkollegiet is that the aspiring community has a charter in which its purpose is stated. The charter also needs to contain clear regulations for any decision-making process affecting the community. Since the purpose of community's religious activity is to be communicated to Kammarkollegiet through bureaucratic textual channels, it needs to be put in print. Although the idea of a "religion" having a charter or a set of sacred texts is a widely accepted understanding in many places around the globe, by demanding a charter, the state can be said to regulate and govern potential future activity of the community by making them accountable to a doctrine. Meanwhile, the community itself becomes restricted and bound to a conduct put in print and articulated through bureaucratic communication.

To paraphrase Richard King, this reflects the particular organizational and literary bias in modern Christian conceptions of "religion." Drawing on the work of Walter Ong, King argues that "[the] literary bias within Christian and post-Christian conceptions of 'religion' has also contributed to a homogenization of other cultures and the way in which they are represented" (1999: 66). The emphasis on scripture can thus be described to furthermore underscore the liberal theological bias in play here. To continue with King, scripture is here transformed into "the primary and authoritative yardstick by which the beliefs and practices of each ['religious'] tradition are to be evaluated" (2011: 49). This is also something that is potentially appealing for "religious" authorities, because the institutionalization through text could contribute in establishing a strict hierarchy within the community itself. In this regard, religion-making from above intersects with religion-making from below in terms of potential benefits and interests. Moreover, the demand that any community has a clearly stated decision-making process is a way for the state to control the community's inner core and future development (Owen and Taira, 2015).

The third demand, which relates to the second, is that the community has a board of directors or a similar governing structure. This might appear as a rather straightforward demand of any community seeking recognition since it means that the community has representatives and spokespersons, but this also means that a hierarchical organizational structure is required. Even though a representative democratic structure is encouraged, this excludes other, postbureaucratic, types of organizational structures (Heckscher and Donnellon, 1994). In this regard, the desire to manage and govern a faith community requires that one or several representatives from the community can speak on behalf of the community. Hence, the state is putting into place channels for accountability, as representatives can be held responsible for the community's thoughts and actions. Moreover, it also transfers certain tasks of policing the community's conduct as "religious" onto the communities' representatives themselves. Again, this is something that potentially fits "religious" authorities' interests because it legitimizes their power position within a community. 
Finally, the community needs a name that sets it apart from "the activity of other [communities]" and that does not infringe upon "sound customs [god sed] or public order." Viewed as a process of religion-making, naming is perhaps the least obtrusive aspect of governance because no guidelines are provided for it, except that the name must be unique. Thus, for the MCK, the recognition has meant that a loosely organized and perceived "sacred" experience centered on copying and sharing information has been turned into an organization (church) and a doctrine (Kopimism).

The second aspect of this fourth guideline and rule, that the community does not infringe upon sound customs or public order, stipulates the accepted and legitimate boundaries of what a faith community's "religious" activities might entail. With this statement the state reifies the modern binaries of private and public on the one hand and "religion" and the social on the other, thus designating legitimate and illegitimate spheres of public activity through the category of "religion." We suggest that this statement potentially serves to reify notions of "religion" as a private sphere of human activity distinct from other secular public spheres of human activity, such as economics, politics, and culture. In the eyes of the state, "religion" thus needs to be fashioned as something private and optional. However, what is being considered as "religion" is not always an optional question of faith. To many Jews or Muslims, being "religious" does not necessarily have anything to do with faith. Instead, kinship, practice, and ethics can be carriers of the "religious" identity (Asad, 1993; Modood, 2007). With this demand follows an assumption that "religion" can be chosen and that it might even be dangerous if allowed to transgress into the public sphere in an incorrect manner. This is evident in the legal paragraphs regulating state support for faith communities. For the state to subsidize a community, the latter needs to "contribute to maintain and enforce the foundational values of the society" (Regulation 1999: 974).

This further supports our claim that the Swedish state has built the discourse of liberal theology of essentialized "religion" into the very fabric of "religious" management. As Talal Asad (2003: 184) has stated, in modern liberal democracies only "religions that have accepted the assumptions of liberal discourse are being commended, in which tolerance is sought on the basis of a distinctive relation between law and morality." The Swedish state here employs law to shape tolerable "religious" subjects as enforcing agents of the state's notions of morality. The point that Asad (2003: 184) raises is that liberal notions of "religion" not only contribute to shaping "religion" in a particular way, but they are in part delineating the boundaries of public space as well: "[t]he public sphere is a space necessarily (not just contingently) articulated by power. And everyone who enters it must address power's disposition of people and things, the dependence of some on the goodwill of others."

\section{Religion-making from below}

In this level of analysis, we seek to assess how the MCK employed a particular notion of "religion" to be acknowledged as a legitimate "religious" group. We divide this analytical level into two sublevels. The first one focuses on how the MCK formulated their chart and organizational structure in the application to Kammarkollegiet, and the second on how the founders of the MCK, Gerson and Nipe, through interventions in the news media, sought to legitimize Kopimism as a real and legitimate "religion."

When Gerson and Nipe embarked the process of recognition, they started by studying Kammarkollegiet's guidelines. Having deliberated the guidelines, they realized that an inspirational framework was needed. They decided to found their community based on the 
Mission Covenant Church of Sweden (MCCS) (Missionskyrkan). As Gerson puts it: "The way we understood it, if we were to get recognition we had to build an organization resembling something the state had already approved." When asked if it was a deliberate and strategic move to choose the MCCS (one of the largest Protestant faith communities in Sweden) in order to accommodate the implicit demands of the Law of 1998, Gerson answers: "I had no idea such a law exists, but this is really funny... Choosing the MCCS was pretty much a random thing. We picked a structure from a larger faith community and it just happened to be the MCCS." This choice however had an impact on the organizational structure of the MCK: "We actually had no formal organization. We existed in IRC-chat rooms, microblogs, forums, and so on. We were and are a flat organization in practice, and we wanted to keep it like that as much as possible" (Gerson, 2014a).

In the MCK's final charter submitted to Kammarkollegiet, their "religious" activity and organizational structure are formalized. The MCK states that it is a "religious missionary community" based on their "believers" acknowledgement and sharing of the same religious foundation." The MCK is missionary in the sense that has a "normative attitude towards the rest of society." It has a "missionary leader" who is described as "the spiritual and foremost representative" of the MCK. Their mission builds on a "foundational axiom" stating that information and the value of information is "sacred." Copying is regarded as an "ethical right," as is the spreading of information. Remixing is more highly valued because it is a matter of "cross copying" using multiple sources. To copy and to remix data handed to a member by another human being is viewed as an act of "respect and a strong expression for acceptance and Kopimist faith." Moreover, it is stated that "the Internet is sacred" and that "code is law." Seen through the eyes of a Kopimist, to live correctly is to cherish these "'religious' foundations" (Kammarkollegiet, 2011b).

Besides the "missionary leader," the MCK has Operators or Ops, who are described as the equivalence of "priests." Their mission is threefold. First, the Op is asked to "to cherish the sacred value of information." Second, the Op organizes "worships" or sessions of kopyacting. These sessions can be analog or digital. During the digital session, members connect their computers to one another's while encouraging the spreading of information to nonparticipating members. Kopyacting also incorporates "the cure of souls," where the Op connects directly to a member who is given the opportunity to "confess" meaning the possibility to privately discuss personal and sensible issues. Third, the Op should strive for "societal change" through "opinion making against surveillance and laws that infringe on the spreading of information, copying and remixing."

The MCK charter also makes clear that worships are to take place at a "Sacred Gathering Point [samverkanspunkt]." This becomes a Gathering Point when an Op places the sign of the MCK, the Sacred Kopimi-Pyramid, at the premises and announces: "I am hereby making these premises into a Gathering Point. Copy and spread." Besides the Sacred KopimiPyramid, the MCK also makes use of other symbols like "Ctrl-C" (copy) and "Ctrl-V" (paste). Their worships are also to be closed by uttering "thx" as an equivalent to "amen."

The application documents reveal how the formation of Kopimism into the MCK, or the formation of the MCK into Kopimism, followed Kammarkollegiet's understanding of how a "religion" is structured. We argue that the MCK thus both reproduces and challenges particular notions of the state's perception of "religion" through this process. However, to challenge the supposed meaning of "religion" is nothing new. On the contrary, during the last few centuries the meaning of "religion" has varied greatly, from having signified Christian truth to being a bundle of world "religions" (Masuzawa, 2005; Nongbri, 2013). 
As we argue, this is a reflection of the power of the category of "religion"-being essentially void of meaning, it can be appropriated to legitimize and delegitimize certain constellations of human activity and interactions.

The emptiness of "religion" is not only reflected in Swedish law, but it also causes confusion and contradiction regarding legal praxis. In this regard, consider the MCK's societal mission. Their focus is on opinion making against surveillance and laws that infringe on the spreading of information, copying, and remixing. Regardless of how one understands this in terms of legitimate or reasonable requests, they articulate a critical position against current Swedish and international laws (i.e. laws on intellectual property and surveillance) by employing the category of "religion." 8 The problem that arises here is that Kammarkollegiet's recognition of the MCK as a faith community might clash with Swedish constitutional law where the MCK, for various reasons, might not be considered as "religious." Our point here is that, regardless of the level "religiousness" attributed to the MCK, the state would need to engage in a theological quest of the MCK's inner nature to be able to answer this question.

\section{Religion-making from the outside}

In this section, we aim to show how the news media came to on the one hand exercise an outside pressure on the MCK regarding what a "real" religion was supposed to be. On the other hand, the news media was also an arena for the founders of the MCK to legitimize and negotiate their "religion" as legitimate. In the news media, Gerson and Nipe were accused of using "religion" for mischievous purposes - that they hijacked it. The idea that "religion" can be hijacked is a prominent one and relates to the liberal theology of essentialized "religion" we discussed earlier. Gerson and Nipe, however, used the news media to convey their message and explain that Kopimism was indeed a real "religion" commensurate with Christianity and Judaism. When talking about these issues with us Gerson appears tired of the allegations of trying to legalize piracy. "For one thing" Gerson says, "there was no need." Gerson explains that what they were doing was beyond the reach of the state. According to Gerson, if it were only a matter of legalizing piracy and fighting the growing apparatus of surveillance and the laws infringing on the sharing of information, they would have continued to work with party politics (Gerson, 2014b). In an article in The New York Times, Gerson moreover explains that "our angle is not to mock religion" and continues, "[w]e recall that Christianity and the Gospels, with their collections of little stories, are examples of copying" (Gerson in Tabligue, 2012).

Nipe has made similar statements. Rebutting this sort of argument, Nipe acknowledges that the recognition by Kammarkollegiet is a sign of a functional rule of law. Nipe continues to state that to "recognize the faith of Kopimists is in line with the values expressed by a whole generation." Nipe then goes on to make references to Martin Luther "who criticized Catholicism." But instead of Catholicism, Nipe talks about the "fundamentalist copyright faith." Nipe, moreover, explains how the MCK in a very real sense builds on a Christian tradition. As Nipe explains:

The Kopimists see Christianity as an exceptional example. There is probably not a single word that Christianity itself has created. Everything is reinterpretation, refinement, and variation of already existing thoughts. Christianity is an extraordinary representation of the remix culture. (Nipe, 2012) 
We suggest that questioning the seriousness of the MCK contributed to making Kopimism into a "religion." The defensive strategy used by Gerson and Nipe, using "religious" syncretism and historical, revolutionary "religious" figures, was a way to articulate Kopimism as a fully legitimate, though different, "religion" along the lines of Abrahamitic "religious" traditions. As such, we suggest questioning the MCK as a "religious" community strengthened the identity of the MCK as a "religion" rather than undermining it. Interestingly, after the recognition by Kammarkollegiet, the news media quickly acknowledged the newly attributed status to the MCK and Kopimism. In local and national journals it was stated that "file sharers now have their own religion" (Dahlström, 2011), that "file sharing becomes a religion" (Jenselius, 2012), that "file sharing as a religion is recognized by the state" (Gillberg, 2012), and that "Kopimism is the newest religion" (Gustafsson, 2012).

Soon after the recognition by Kammarkollegiet, news of the MCK reached international media. The aforementioned article in The New York Times had the following headline: "In Sweden, Taking File Sharing to Heart. And to Church." One paragraph reads: "people almost everywhere are file sharing these days, using computers to download music, films, books or other materials, often ignoring copyrights. In Sweden, however, it is a religion" (Tabligue, 2012; see also Vuorela, 2012).

It appears to us that the news media's ambiguous recognition of Kopimism as a "religion" has played an important part in making Kopimism viable and attractive in the eyes of individuals seeking potential legal protection under the freedom of "religion" laws for what, according to Swedish law, is illegal. When asked about this, Gerson confirms that many members appear to have become Kopimists based on this assumption. However, Gerson does not know the number of members that joined the MCK for these reasons (Gerson, 2014a). To substantiate this claim, however, more research is needed.

\section{Conclusion}

Our reading of the recognition of the MCK reveals that it was a threefold performative act that, through the lens of Dressler and Mandair's analytical schema, brings important aspects regarding the management of "religion" in Sweden to the fore. First, through the acknowledgement of the MCK the state reified its exercise of power over the "religious" - that is regulating what is and what is not "religion"-through a bureaucratic exercise of sovereign power. Second, it simultaneously participated in the construing of the association itself in terms of staking the conditions of the MCK's structure, message, and followers. Third, we argue that, just as the state had an important formative role for the MCK, the MCK itself had to negotiate its formation as a faith community and as a religion within the discursive boundaries set up by the state. Our analysis poses challenges regarding state neutrality and "religion" in Sweden. In other words, even if the state were to treat all "religions" equally, for a "religion" to become recognizable it needs to be fashioned according to a particular understanding of "religion" through various techniques of religion-making. State neutrality is thus undermined before the question is even posed. Our analysis moreover shows that the ambiguity concerning exactly what the category of "religion" is taken to mean moreover that it is possible for virtually any community to be recognized as a "religious" one - even one who's religious practice is contrary to Swedish law and international law.

Throughout the article, we have abstained from commenting on the faith and practices of the MCK. Indeed, our aim has not been to judge whether Kopimism is a real "religion" or not. That would be a whole other project than ours. We would however like to add that 
based on our interviews and informal meetings with the Gerson, the desire of Gerson and Nipe to get recognition for what they saw as "religion" was honest and sincere and not merely a PR stunt as suggested in the news media. We would also like to emphasize that this article is dealing with one case of recognition and the results and arguments of this article should be treated as such. We identify four fields for future research. First, a study is necessary of the MCK since the recognition process as this might reveal how the formation during the recognition procedure has affected the community on a more long-term basis. Second, an analysis of the media, and especially the news media, as an arena for religionmaking might reveal whether the MCK's public image - as a religion for Internet pirates - has contributed to attracting members. Third, a broader approach to how other faith communities have related to the procedure would prepare for a comparative and more in-depth analysis. Finally, we also see the need for an in-depth genealogical study of "religious-secular" binary vis-à-vis religion-making in Sweden.

\section{Funding}

Vetenskapsrådet 10.13039/501100004359. Riksbankens Jubileumsfond 10.13039/501100004472.

\section{Notes}

1. Our approach to the categories "religious" and "religion" draws on discourse theory. We understand the categories as anti-foundational, meaning that we treat them as empty categories that are given a contingent (and often contradictory) meaning through contingent articulatory practices. We write the categories within quotation marks to emphasize this aspect. On this issue, see Jacob Torfing (1999).

2. For a summary and explanation of these grants and advantages see Regulation 1999:974 regulating the Swedish Commission for Government Support to Faith Communities (Nämnden för Statligt Stöd till Trossamfund). In 2013 the Ministry distributed 75.2 million sek (Swedish Kroner) to faithbased communities.

3. The Swedish Supreme Administrative Court has made a different interpretation of the Regulation 1999:974 than the government. Based on this interpretation the Jehovah's Witnesses have appealed. The legal dispute has not been resolved (see Case 4496-12, 2013).

4. This would call for another type of analysis of the MCK, it's motives, ambitions, members, and so on.

5. Gerson has been given the opportunity to check all his quotations.

6. Sweden is home to Piratbyrain (The Bureau of Piracy, an organization supporting "Internet pirates"), The Pirate Bay (allegedly the world's largest Web site for file sharing), and the Pirate Party, which in 2010 gained seats in the European Parliament (see further Lindgren, 2013; Lindgren and Linde, 2012).

7. The Swedish word for worship derives from the German Gottesdienst and consists of two agglutinated words with Lutheran connotations, that is "God" (gud) and "service" (tjänst).

8. Surveillance of the Internet and censorship in regard to file sharing has been put into action through acts and laws like the FRA Law in Sweden, the Intellectual Property Rights Enforcement Directive in the EU and the Stop Online Piracy Act, and the Preventing Real Online Threats to Economic Creativity and Theft of Intellectual Property Act in the USA.

\section{References}

Asad T (1993) Genealogies of Religion: Discipline and Reasons of Power in Christianity and Islam. New York: The Johns Hopkins University Press.

Asad T (2003) Formations of the Secular. Stanford: Stanford University Press. 
Bäckström A, Edgardh N and Pettersson P (2004) Religious Change in Northern Europe. The Case of Sweden. Stockholm: Verbum förlag.

Beaman LG (2005) Religion and rights: The Illusion of freedom and the reality of control. Culture and Religion: An Interdisciplinary Journal 6(1): 7-29.

Beaman LG (2012) Is religious freedom impossible in Canada? Law, Culture and the Humanities 8(2): $266-284$.

Bexell O (2003) Sveriges Kyrkohistoria: Folkväckelsens Och Kyrkoförnyelsens Tid. Stockholm: Verbum förlag.

Bill 1997/98:116; Proposition (1997/98:116) Staten och trossamfunden: Bestämmelser om Svenska kyrkan och andra trossamfund. Socialdepartementet, Stockholm.

Brown W (2008) Regulating Aversion: Tolerance in the Age of Identity and Empire. Princeton: Princeton University Press.

Casanova J (2011) The Secular, secularizations, secularisms. In: Calhoun C, Juergensmeyer M and VanAntwerpen J (eds) Rethinking Secularism. London and New York: Oxford University Press, pp.54-74.

Case 4496-12; Mål nr. 4496-12 (2013). Högsta förvaltningsdomstolen, Stockholm, 8 November.

Cavanaugh WT (2009) The Myth of Religious Violence: Secular Ideology and the Roots of Modern Conflict. New York: Oxford University Press.

Dahlman P (2009) Kyrka och Stat i 1860 års Svenska Religionslagstiftning. Skellefteå: Arcos.

Dahlström F (2011) Han vill att fildelning ska klassas som religion. Uppsalatidningen, 8 April.

Dareberg L (2012) Låt oss starta en religion! Församlingar klarar sig utan myndighetens försyn. Sydsvenskan, 1 February.

Dressler M and Mandair A (2011) Secularism and Religion-Making. Oxford and New York: Oxford University Press.

Edge PW (2006) Religion and Law: An Introduction. Aldershot: Ashgate.

Editorial (2012) Kammarkollegiet undergräver religionsfriheten. Kyrkans tidning, 12 January.

Ekstrand T (2002) Folkkyrkans Gränser: En teologisk Analys av Övergången Från Statskyrka till Folkkyrka. Stockholm: Verbum förlag.

Enkvist V (2013) Religionsfrihetens Rättsliga Ramar. Uppsala: Iustus förlag.

Fitzgerald T (2007) Discourse on Civility and Barbarity: A Critical History of Religion and Related Categories. Oxford: Oxford University Press.

Foucault M (1991) Governmentality. In: Burchell G, Gordon C and Miller P (eds) The Foucault Effect: Studies in Governmentality. Chicago: University of Chicago Press, pp.87-104.

Gerson I (2013) Interview with Gerson. By Nilsson PE, Uppsala, 25 October.

Gerson I (2014a) Interview with Gerson. By Nilsson PE, Uppsala, 7 May.

Gerson I (2014b) Correspondence with Gerson. By Nilsson PE.

Gillberg V (2012) “Fildelningsreligion” erkänns av staten, Metro, 4 January.

Green TH (2011) Responding to Secularization: The Deaconess Movement in Nineteenth-Century Sweden. Leiden: Brill.

Gustafsson S (2012) Kopimismen nyaste religionen. Tidningarnas telegrambyrå, 1 January.

Heckscher C and Donnellon A (1994) The Post-bureaucratic Organization: New Perspectives on Organizational Change. London: Sage.

India XJ (2005) Analytics of the modern: An Introduction. In: India XJ (ed.) Anthropologies of Modernity: Foucault, Governmentality, and Life Politics. Oxford: Blackwell Publishing.

Jenselius M (2012) Att fildela i sverige - och nu blir fildelningen religion. PC För alla, 10 February.

Kammarkollegiet (2011a) Registrering av trossamfund. Beslut. Dnr 19.3.1-04562-2011. Förvaltningsrättsliga enheten, Stockholm.

Kammarkollegiet (2011b) Konstitution för det missionerande kopimistsamfundet. Dnr 19.3.1-4562-11. Förvaltningsrättsliga enheten, Stockholm.

King R (1999) Orientalism and Religion: Postcolonial Theory, India and 'the Mystic East'. London and New York: Routledge. 
King R (2011) Imagining religions in India: Colonialism and the mapping of South Asian history and culture. In: Dressler M and Mandair A (eds) Secularism and Religion-Making. Oxford and New York: Oxford University Press, pp.37-61.

Law of 1998:1591; Lag om Svenska kyrkan (1998:1591). Socialdepartementet, Svensk författningssamling, Stockholm.

Law of 1998:1593; Lag om trossamfund (1998:1593). Socialdepartementet, Svensk författningssamling, Stockholm.

Lejon KO (2013) Lutheranism or secularism? Perspectives on the Lutheran foundation of the Scandinavian welfare states - and signs of new religious impulses in the contemporary secular setting. Theofilos 6(2): 4-12.

Lindgren S (2013) Pirate panic. Information, Communication and Society 16(8): 1242-1265.

Lindgren S and Linde J (2012) The subpolitics of online piracy: A Swedish case study. Convergence 18: $143-164$.

McCutcheon RT (2007) "They licked the platter clean": On the co-dependency of the "religious" and the secular. Method and Theory in the Study of Religion 19: 173-199.

McGoldrick D (2006) Human Rights and Religion: The Islamic Headscarf Debate in Europe. Oxford: Hart.

Mahmood S (2006) Secularism, hermeneutics, and empire: The Politics of Islamic reformation. Public Culture 18(2): 323-347.

Masuzawa T (2005) The Invention of World Religions. Or, How European Universalism Was Preserved in the Language of Pluralism. Chicago: University of Chicago Press.

Modood T (2007) Multiculturalism: A Civic Idea. London: Polity Press.

Nipe G (2012) Ett sätt att förminska andras övertygelse. Dagen, 12 January.

Nongbri B (2013) Before Religion. A History of a Modern Concept. New Haven and London: Yale University Press.

Norris P and Inglehart R (2004) Sacred and Secular: Religion and Politics Worldwide. Cambridge: Cambridge University Press.

Owen S and Taira T (2015) The Category of 'religion' in public classification: Charity registration of the Druid network in England and Wales. In: Fitzerald T, Goldenberg N and Stack T (eds) Religion as Category of Governance and Sovereignty. Leiden: Brill, pp.90-114.

Petrén G and Ragnemalm H (1980) Sveriges Grundlagar Med Tillhörande Författningar Och Förklaringar. Stockholm: Liber förlag.

Pettersson P (2011) State and religion in Sweden: Ambiguity between disestablishment and religious control. Nordic Journal of Religion 24: 119-135.

Pettersson T (1988) Bakom Dubbla Lås: En Studie i Små Och Långsamma Värderingsförändringar. Stockholm: Institutet för framtidsstudier, 1988.

Radan P, Meyerson D and Croucher RF (2005) Law and Religion. God, the State and the Common Law. London and New York: Routledge.

Regulation 1999:974 (1999) Förordning (1999:974) om statsbidrag till trossamfund. Svensk författningssamling, Socialdepartementet, Stockholm.

Riis O (1994) Patterns of secularization in Scandinavia. In: Petterson T and Riis O (eds) Scandinavian Values - Religion and Morality in the Nordic Countries. Uppsala: Uppsala University.

Strömberg H (2007) Hädiska Tankar Om Religionsfriheten. Visby: Rättsfonden.

Sullivan WF (2005) The Impossibility of Religious Freedom. Princeton: Princeton University Press.

Tabligue J (2012) In Sweden, taking file sharing to heart: And to church. The New York Times, 25 July.

Taylor C (2008) What is secularism. In: Levey G and Modood T (eds) Secularism, Religion and Multicultural Citizenship. Cambridge: Cambridge University Press.

Thalén P (2006) Att Mäta Religiositet: Filosofiska Perspektiv På Kvantitativ Religionsforskning. Uppsala: Uppsala Universitetstryck.

Therborn G (2012) Världen: En Introduktion. Malmö: Liber.

Torfing J (1999) New Theories of Discourse: Laclau, Mouffe and Zizek. London: Blackwell Publishers. 
Turner BS (2011) Religion and Modern Society: Citizenship, Secularisation and the State. Cambridge: Cambridge University Press.

Vuorela M (2012) Religiøse internetpiraters mantra: Kopier og spred. Politiken, 10 January.

Waller S (1964) Religionsfrihet. Stockholm: Ecklesiastikdepartementet.

Willander E (2013) What Counts as Religion in Sociology? The Problem of Religiosity in Sociological Methodology. Uppsala: Department of Sociology, Uppsala University.

Zetterman J (2012) De vill fildela i skydd av religionen. Dagen, 22 March.

\section{Author biographies}

Per-Erik Nilsson works as a researcher at the Impact of Religion Research Program, Uppsala University. He is currently stationed (2015-18) in France at the l'IEP in Aix-enProvence where is doing research on French secularism, populism, and nationalism.

Victoria Enkvist is currently working as a researcher and teacher at the Faculty of Law and within the Impact of Religion Research Program, both at Uppsala University. Enkvist is a specialist on questions concerning freedom of religion in Sweden and Europe. 